\title{
Antioxidant and antibacterial activities of hot water and enzyme extracts from plants containing tannin pigments
}

\author{
Hwa-Jin Suh, Yeon-Soon Kim, Sanggyu Park, Shin Park* \\ Division of Life and Environment, Daegu University, Gyeongsan 38453, Korea
}

\section{탄닌계 색소를 함유한 식물의 열수추출물과 효소추출물의 항산화 및 항세균 활성}

\author{
서화진 · 김연순 · 박상규·박신* \\ 대구대학교 생명환경학부
}

\begin{abstract}
The purpose of this study was to investigate the antioxidant and antibacterial activities of hot water and enzyme extracts obtained from plants containing tannin pigments. The antioxidant activities were confirmed by analysis of the total phenolic content, determination of the DPPH and $\mathrm{ABTS}^{+}$radical scavenging activities and lipid peroxidation experiments. The antibacterial activities were verified using disc diffusion methods against Escherichia coli and Listeria grayi. The $\mathrm{IC}_{50}$ values representing the DPPH radical scavenging activities of the hot water extracts were determined to be 9.4 to $21.5 \mu \mathrm{g} / \mathrm{mL}$, while the $\mathrm{IC}_{50}$ values of the enzyme extracts were 3.7 to $6.58 \mu \mathrm{g} / \mathrm{mL}$. It was confirmed that both extracts exhibited a good antioxidant activity comparable to that of ascorbic acid (i.e., $10.5 \mu \mathrm{g} / \mathrm{mL}$ ), which is commonly employed for comparison. In addition, the TPC and $\mathrm{ABTS}^{+}$radical scavenging activities were also significant, and lipid peroxidation experiments demonstrated $\geq \mathbf{5 0} \%$ suppression compared to the negative control. Furthermore, the enzyme extracts showed a higher level of activity than the hot water extracts, and the presence of greater quantities of tannin-containing polyphenols in enzyme extracts ensures a high activity even when low extraction temperatures are employed. These results clearly indicate that tannin-containing plant extracts may play an important role in suppressing the free radicals produced by oxidative stress in living organisms, and therefore could exhibit potential for application as new biological materials following additional in-depth research.
\end{abstract}

Key words : antibacterial, antioxidant, enzyme extraction, lipid peroxidation, tannin

\section{서 론}

인체 내에서 산화적 스트레스를 유발하는 자유라디칼은 환경오염, 음주, 흡연, 화학약품 등에 의해 생성된다. 또한 생체내의 자유라디칼 반응에 의해 생성되는 활성산소 및 산화질소는 단백질의 불활성화, 조직의 손상, 유전자 변이

*Corresponding author. E-mail : spark@daegu.ac.kr Phone : 82-53-850-6751, Fax : 82-53-850-6759

Received 11 June 2019; Revised 19 August 2019; Accepted 04 October 2019.

Copyright (c) The Korean Society of Food Preservation. All rights reserved.
등을 유발하여 노화, 퇴행성질환, 신경질환, 대사증후군 등 과 같은 질환의 주요 원인으로 보고되고 있다. 신체에는 이러한 산화적 스트레스로부터 세포막과 세포내 물질을 보호하기 위해 항산화 기전이 존재하는데 그중 하나는 체내 존재하는 항산화 효소에 의해서, 나머지는 생체 내 여러 가지 항산화 물질과 식이를 통하여 공급되는 항산화 영양소 와 폴리페놀류와 같은 항산화제에 의한 것이다(1). 현재 우리 주변에서 접할 수 있는 천연 항산화제는 비타민 $\mathrm{C}$, 탄닌, 안토시아닌, 토코페놀, 카로티노이드류, 플라보노이 드류 등이 있으며 생체 내에서 노화를 억제시키거나, 동맥 경화증, 염증, 퇴행성 질환 및 암을 예방하는데 아주 효과적 
인 것으로 보고되고 있다(2,3). 최근 인간의 삶의 질에 대한 관심이 높아지면서 노화 및 만성적 질병을 예방, 치료함으 로써 건강한 삶을 추구하기 위한 천연물로부터 항산화 기능 성 생리활성 물질에 대한 연구가 활발하게 진행되고 있다. 탄닌은 식물계의 열매, 잎, 줄기, 껍질, 충류 등 풀을 제외한 거의 모든 식물에 널리 분포하는데, 단백질과 결합하는 특 성을 지닌 폴리페놀 구조로 되어 있으며 분자량이 600-2,000 정도의 수용성 화합물이다(4). 그 수용액은 수렴 성이 강하고 단백질, 아세트산납, 석회, 알칼로이드 등과 불용성의 침전을 형성하며 식물에 있어서 자체의 세균 등에 대한 방부적 보호 작용을 한다(5,6).

케브라초(Schinopsis lorentzii)는 옻나무과의 교목 케브라 초의 심재로부터 얻어지며, 추출물에는 탄닌이 많이 함유 되어 있다. 밤나무(Castanea crenata var. dulcis)는 아시아, 유럽, 북아메리카 등의 온대지역에 13종이 분포한다. 가자 나무(Terminalia chebula) 과즙에서는 황색 염료를 추출하 는데, 이것을 미로발란이라고 한다. 약재로 사용되는 과실 은 핵과로 달걀모양으로 바깥 면은 황갈색-갈색의 광택이 있고 세로로 5 개의 두드러진 주름과 그 사이에 불규칙한 주름이 있다. 아카시아 와틀(Acacia decurrens var. mollis)은 남아프리카, 남아메리카, 인도 등 각지에서 재배되고, 콩과 Acacia속 여러 종류의 수피를 말한다. 보통 탄닌의 함량은 $35-39 \%$ 이다.

본 연구는 천연염색에서 주로 사용되어 온 천연염료 중 에서 화장품, 식품 등의 산업에 적용이 가능할 것으로 판단 되는 소재를 발굴하기 위한 기초연구를 수행하였다. 탄닌 계 색소화합물을 함유하고 있는 4종의 식물, 즉 옻나무 (Quebracho), 가자나무(Myrobalan), 밤나무(Chestnut), 아카 시아(Wattle)로 부터 열수추출물과 효소추출물을 얻어 항 산화 활성 및 항세균 활성을 비교 분석함으로써 생리활성물 질로서의 가치와 유용성에 대한 연구를 수행하였고 또한 $100^{\circ} \mathrm{C}$ 열수추출에 의한 기능성분의 변성 및 유기용매 추출 에 의한 유독성 등을 피하고자 유기용매를 사용하지 않고 저온조건에서 충분한 양의 기능성분을 확보할 수 있는 방법 으로 효소처리를 통한 저온·감압추출조건에 대한 연구를 수행하였다.

\section{재료 및 방법}

\section{실험재료 및 추출조건}

본 연구에 사용된 옻나무(케브라초), 가자나무(미로발 란), 밤나무 껍질(체스넛), 아카시아(와틀)은 2018년 3월에 경북 영천시에서 구입하여 사용하였으며, 시료의 학명, 일 반명, 사용된 부위 및 적용 효소에 대해서는 Table 1 에 나타 내었다. 열수추출은 건조된 시료 $100 \mathrm{~g}$ 에 증류수를 가하여 $1 \mathrm{~L}$ 로 맞춰 $100^{\circ} \mathrm{C}$ 에서 4 시간 가열하고 여과한 후, 감압농축 및 동결건조 과정을 거쳐 분말화하여 실험에 사용하였다. 효소추출은 시료의 특성, 에너지 효율, 추출시간을 달리하 여야 하나, 일반 열수 추출과의 비교를 위해 저온조건인 $60 \pm 2{ }^{\circ} \mathrm{C}$ 에서 4 시간 효소반응 및 추출을 동시에 진행한 후 효소 불활성화를 위해 $90^{\circ} \mathrm{C}$ 에서 30 분 노출시킨 후 추출액은 고밀도 포켓 필터를 사용해 여과, 농축, 동결건조를 통해 분말화한 후 사용 전 까지 $4^{\circ} \mathrm{C}$ 에서 보관하였다. 또한 효소추 출 조건을 설정하기 위하여 사용한 효소는 식품첨가물로 고시되어 있는 Novozyme사(Denmark)의 효소를 사용하였 다. 내열성 전분분해효소(a-amylase)인 Termamyl, 중온성 전분분해효소(a-amylase)인 Ban800MG, 셀룰로우즈 분해 효소인 Cellu-Bio를 사용하여 소재의 안전성을 높였고, 효 소 처리량은 시료 $100 \mathrm{~g}$ 에 중량 대비 $4 \mathrm{~g}$ 을 각각 처리한 후 증류수를 가하여 $1 \mathrm{~L}$ 로 맞춘 후 $\mathrm{pH}$ 는 중성조건에서 진행되었다. 실험에 사용된 용매 및 시약은 $\operatorname{Duksan}(\mathrm{GR}$ grade), Sigma-Aldrich Co.(St. Louis, MO, USA) 제품을 사용 하였다.

\section{총 페놀 함량 분석}

추출된 시료의 총 폴리페놀 함량을 평가하기 위해 Folin-Ciocalteu법(7)을 이용하였다. 즉 시료 $100 \mu \mathrm{L}$ 와 Folin-Ciocalteu 시약 $50 \mu \mathrm{L}, 20 \% \mathrm{Na}_{2} \mathrm{CO}_{3} 850 \mu \mathrm{L}$ 를 혼합한 후 2 시간 동안 암실에서 반응시킨 후, 분광광도계(UV-1800 Shimadzu, Kyoto, Japan)를 이용하여 $765 \mathrm{~nm}$ 에서 측정하였 다. 총 페놀 함량은 gallic acid를 이용하여 작성한 표준검량 곡선을 표준선으로 하여 계산하였으며, 총 폴리페놀 함량 을 추출물 시료 $1 \mathrm{mg}$ 중 존재하는 양으로 계산하여 단위를 gallic acid equivalents(GAE mg/g)로 작성하였다. Gallic acid 의 농도는 $10-500 \mu \mathrm{g} / \mathrm{mL}$ 가 되도록 하여 위와 같은 방법으로 $765 \mathrm{~nm}$ 에서 흡광도를 평가하여 작성하였다.

Table 1. Substrate information used in this study

\begin{tabular}{ccccc}
\hline & Sample & & \multirow{2}{*}{ Part used } & Enzyme \\
\hline Scientific name & Common name / Korean & Termamyl \\
Castanea crenata var. dulcis & Chestnut / 밤나무 & Fruit Bark & Ban 800 \\
Terminalia chebula & Myrobalan / 가자나무 & Fruit & Ban 800, Cellu Bio \\
Acacia decurrens var. mollis & Quebracho / 옻나무 & Bark & Ban 800, Cellu Bio \\
\hline
\end{tabular}




\section{DPPH radical scavenging assay}

Brand-Williams 등의 방법(8)에 따라 DPPH(2,2-diphenyl-1picrylhydrazyl) 라디칼 소거 활성을 평가하였다. $6 \times 10^{-5} \mathrm{M}$ $\mathrm{DPPH}$ 를 methanol에 녹인 후, $\mathrm{DPPH}$ 라디칼 용액 $900 \mu \mathrm{L}$ 와 시료 $100 \mu \mathrm{L}$ 를 혼합하여 5 분간 반응시킨 후 분광광도계 (UV-1800 Shimadzu, Kyoto, Japan)를 사용하여 $517 \mathrm{~nm}$ 에서 흡광도를 측정하였다. DPPH 라디칼의 소거능은 아무 것도 첨가하지 않은 대조군과 시료 첨가 후 흡광도의 변화로 하여 다음 식으로 계산하였다.

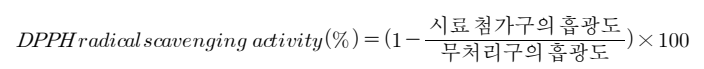

시료의 농도별 DPPH 라디칼 소거능(전자공여능, \%)을 도식화하여 전자공여능 $50 \%$ 일 때의 시료 농도를 $50 \%$ 소거 농도 $\left(\mathrm{IC}_{50}\right)$ 로 나타내었다.

\section{$\mathrm{ABTS}^{+}$radical scavenging assay}

ABTS(2,2'-azino-bis(3-ethylbenzothiazoline-6-sulfonic acid) diammonium salt) 라디칼 소거활성을 이용한 항산화 력 측정은 ABTS cation decolorization assay 방법(9)에 의하 여 측정하였는데, $7 \mathrm{mM} \mathrm{ABTS}$ 와 $2.4 \mathrm{mM}$ potassium persulfate를 섞어 12 시간 이상 암소에 방치하여 청록색의 $\mathrm{ABTS}$ 라디칼을 형성시켜 냉장 보관하였으며, radical stock solution은 $734 \mathrm{~nm}$ 에서 흡광도 값이 $0.70 \pm 0.02$ 이 되도록 에탄올로 희석하였다. 이 용액 $0.9 \mathrm{~mL}$ 에 농도별로 제조한 각 시료용액 $0.1 \mathrm{~mL}$ 를 가한 후 실온에서 7분간 반응시킨 후, 반응액의 흡광도 변화를 $734 \mathrm{~nm}$ 에서 측정하였다. $\mathrm{ABTS}^{+}$radical cation decolorization 정도는 시료용액 첨가 군과 무첨가군의 흡광도 감소율로 나타내었다.

ABTS radical decolorization $(\%)=\left(1-\frac{\text { 시료첨가구의흡광도 }}{\text { 무처리구의흡 광도 }}\right) \times 100$

\section{Lipid peroxidation inhibition assay}

지질 과산화물을 측정하기 위하여 쥐의 간 조직을 phosphate buffer saline(PBS)을 사용하여 $4^{\circ} \mathrm{C}$ 에서 균질화하 였다. 그 후 $10,000 \mathrm{rpm}$ 에 5 분 동안 원심분리하여 상층액을 사용하였다. $0.15 \mathrm{M}$ potassium chloride와 각각의 균질화된 조직 $500 \mu \mathrm{L}$ 에 시료를 처리하여 $20 \mathrm{mM}$ ferric chloride 100 $\mu \mathrm{L}$ 를 가하였다. 그 후 $37^{\circ} \mathrm{C}$ incubator에서 30 분간 반응시킨 후 $15 \% \mathrm{TCA}, 0.38 \% \mathrm{TBA}$ 와 $0.5 \% \mathrm{BHT}$ 가 포함된 $0.25 \mathrm{~N}$ cold- $\mathrm{HCl}$ 을 $500 \mu \mathrm{L}$ 를 첨가하였다. $90^{\circ} \mathrm{C}$ 에서 60 분간 열을 가해준 후 $5,000 \mathrm{rpm}, 4^{\circ} \mathrm{C}$ 에서 5 분 동안 원심분리하여 상층 액을 흡광도 $532 \mathrm{~nm}$ 파장에서 thiobarbituric acid reactive substances(TBARS)를 측정하였다(10).

\section{항균 실험}

식물 추출물에 대한 항균 실험을 하기 위해 그람 양성균
인 Listeria grayi와 그람 음성균인 Escherichia coli가 사용되 었다. Disc diffusion method법(11)을 이용하여 식물 추출물 의 항균 활성을 검증하였다. 디스크 확산법을 실험하기 하 루 전에 각각의 균주를 각 배지 $5 \mathrm{~mL}$ 에 24시간 동안 200 $\mathrm{rpm}$ 으로 배양한 후 사용하였으며, 균수를 $1 \times 10^{6} \mathrm{cfu} / \mathrm{mL}$ 로 보정하여 실험을 진행하였다. 고체배지에 배양한 액상 균 주를 골고루 도말한 후 직경 $8 \mathrm{~mm}$ 의 paper disk에 식물 추출물을 절대 농도로 $1 \mathrm{mg}$ 이 되도록 처리하여 완전히 흡 수시킨 후 이 paper disk를 고체배지에 놓고 $37^{\circ} \mathrm{C}$ incubator 에서 16 시간 배양시켜 시료를 처리한 paper disk 주위의 inhibition zone(clear zone)의 직경을 측정하여 비교 분석하 였다.

\section{결과 및 고찰}

\section{총 페놀 함량 분석}

식물계에 널리 분포되어 있는 페놀성 화합물은 분석이 간편하여 초기 모니터링 실험으로 많이 사용되고 있으며 페놀성 화합물 함량이 높을수록 항산화, 항균, 항암작용 등의 다양한 생리 활성을 나타내는 것으로 알려져 있다(12). 페놀성 화합물 중 대표적인 유효물질로 탄닌 성분을 꼽을 수 있으며 이들의 유익한 효능을 확보하기 위해 실험을 진행하였다. 본 실험에서 사용된 식물 추출물의 총 페놀 함량(TPC, total phenolic contents)의 분석 결과는 Fig. 1에 나타난 바와 같다. 분석된 열수추출물의 TPC는 0.33-0.63 $\mathrm{GAE} \mathrm{mg} / \mathrm{g}$ 의 범위를 나타내었는데 그중 옻나무(케브라쵸) 열수추출물이 $0.63 \mathrm{GAE} \mathrm{mg/g}$ 으로 다른 추출물에 비해 높은 수준으로 분석되었다. 그리고 효소추출물의 TPC는 0.52-0.78 GAE mg/g의 범위를 나타내었는데 옻나무(케브 라쵸) 효소추출물이 $0.78 \mathrm{GAE} \mathrm{mg/g}$ 으로 열수추출물과 마

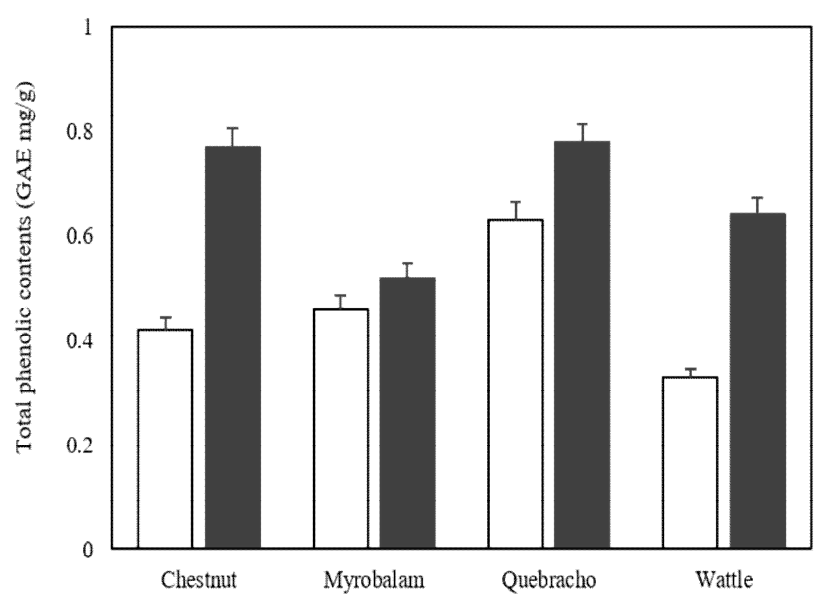

Fig. 1. Total phenolic contents of various plants.

Open bars are hot-water extracts and dark gray bars are enzyme extracts. Data are expressed as mean $\pm \mathrm{SD}$ of triplicate experiments. 
찬가지로 가장 높게 나타났다. 두 추출 조건을 비교해 볼 때 $100^{\circ} \mathrm{C}$ 열수추출물 보다 저온 효소 추출물에서 높은 수준 의 총 페놀성 화합물이 검출되어졌다. 일반적으로 천연 식 물에 함유된 페놀 화합물은 유해한 라디칼에 전자를 공여하 여 라디칼을 제거함으로써 체내의 산화적 스트레스를 경감 시켜 주는데, 페놀 함량과 항산화 활성은 양의 상관관계를 나타낸다.

\section{라디칼 소거능 평가}

$\mathrm{DPPH}$ 는 화학적으로 안정화된 자유라디칼을 가지고 있 는 물질로 ascorbic acid, tocopherol, polyhydroxy 방향족 화 합물 등에 의해 환원되어 짙은 자색이 탈색되는데, 이것은 다양한 천연 소재로부터 항산화물질을 검색하는데 많이 이용되고 있다(13). 열수추출 및 효소반응 추출에 의해 얻어 진 식물추출물의 전자공여능을 측정한 결과는 Fig. 2 와 같 다. DPPH 라디칼 소거활성은 라디칼을 $50 \%$ 소거하는데 필요한 물질의 농도로 나타낼 수 있으며 이 농도는 낮을수 록 우수한 활성을 가진다. 열수추출에 의해 얻어진 소재에 서는 밤나무 껍질(체스넛) 추출물이 $9.4 \mathrm{\mu g} / \mathrm{mL}$, 아카시아 (와틀) $12.91 \mu \mathrm{g} / \mathrm{mL}$, 옻나무(케브라쵸) $15.4 \mu \mathrm{g} / \mathrm{mL}$, 가자나 무(미로발란) $21.5 \mathrm{\mu g} / \mathrm{mL}$ 순으로 나타났으며, 효소추출물 은 가자나무(미로발란) $3.7 \mu \mathrm{g} / \mathrm{mL}$, 밤나무 껍질(체스넛) $5.95 \mathrm{\mu g} / \mathrm{mL}$, 옻나무(케브라쵸) $6.02 \mathrm{\mu g} / \mathrm{mL}$, 아카시아(와틀) $6.58 \mathrm{\mu g} / \mathrm{mL}$ 순으로 4종 모두에서 우수한 활성을 나타내었 다. 비교 물질로 주로 사용되는 ascorbic acid의 $\mathrm{IC}_{50}$ 이 5-10 $\mu \mathrm{g} / \mathrm{mL}$ 수준인 것을 감안해 볼 때 효소추출물의 DPPH 라디 칼 소거능력은 상당히 높은 수준의 항산화력을 가지는 것을 확인하였다(14).

$\mathrm{ABTS}^{+}$와 potassium persulfate를 암소에 방치하면 $\mathrm{ABTS}^{+}$ 라디칼이 생성되는데 추출물의 항산화력에 의해 $\mathrm{ABTS}^{+}$ 라디칼이 소거되어 라디칼 특유의 색인 청록색이 탈색된다

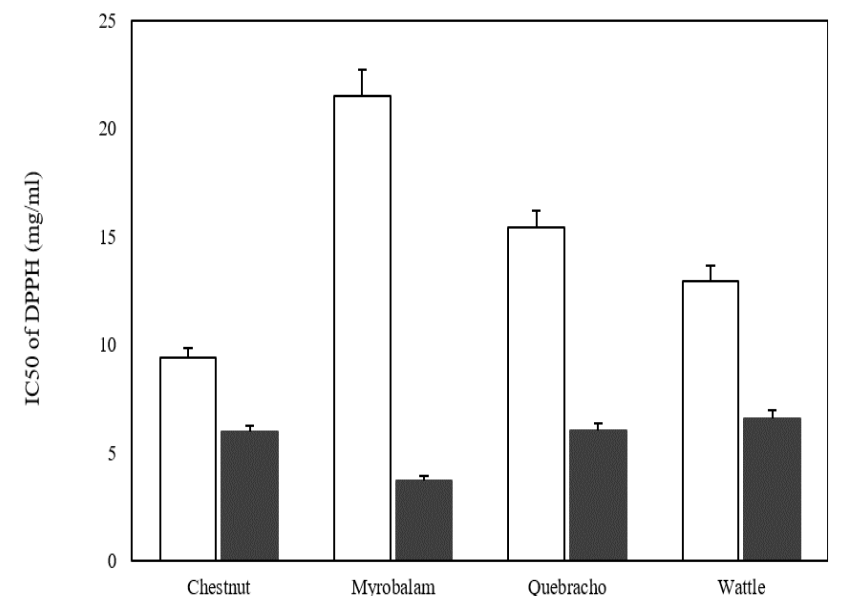

Fig. 2. DPPH radical scavenging activity of hot-water extracts (open bars) and enzyme extracts (dark gray bars) from various plants.

The concentrations $\left(\mathrm{IC}_{50}\right)$ required to exert $50 \%$ of DPPH radical were tested. Data are expressed as mean $\pm \mathrm{SD}$ of triplicate experiments.
(15). 이와 같이 $\mathrm{ABTS}^{+}$라디칼 탈색반응은 이미 생성된 자유라디칼의 제거 정도를 흡광도로 나타내어 $\mathrm{ABTS}^{+}$라디 칼의 소거 활성능을 측정하는 방법으로 $\mathrm{ABTS}^{+}$라디칼 탈색 반응이 1 분 안에 종료되므로 단시간 측정할 수 있고, 소수성 과 친수성 모두에 적용 가능하다(1). 각 식물의 열수추출물 및 효소추출물의 $\mathrm{ABTS}^{+}$라디칼 소거 활성을 측정한 결과는 Fig. 3에 나와 있는바와 같이 열수추출물 및 효소추출물 모두에서 DPPH 라디칼 소거능의 결과보다 저해 활성이 높게 나타났다. 이는 $\mathrm{ABTS}^{+}$라디칼이 $\mathrm{DPPH}$ 라디칼 보다 좀 더 강력한 산화물질이기 때문인 것으로 사료된다(16). 열수추출의 $\mathrm{ABTS}^{+}$라디칼 $\mathrm{IC}_{50}$ 은 가자나무(미로발란), 밤 나무 껍질(체스넛), 아카시아(와틀), 옻나무(케브라쵸) 추출 물 순이였으며, 효소처리 추출물에서는 옻나무(케브라쵸), 밤나무 껍질(체스넛), 가자나무(미로발란), 아카시아(와틀) 순으로 모두 높은 수준의 항산화력을 나타내었다.

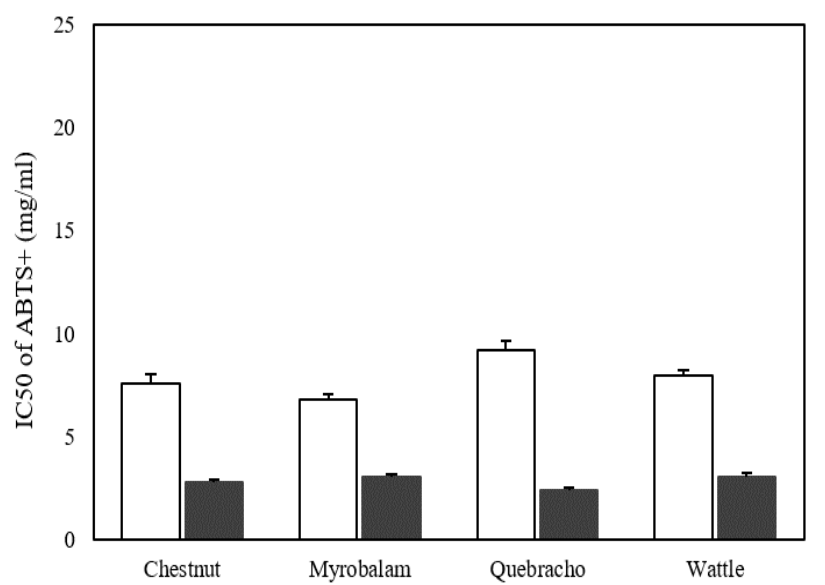

Fig. 3. ABTS+ radical scavenging activity of hot-water extracts (open bars) and enzyme extracts (dark gray bars) from various plants.

The concentrations $\left(\mathrm{IC}_{50}\right)$ required to exert $50 \%$ of $\mathrm{ABTS}^{+}$radical were tested. Data are expressed as mean $\pm \mathrm{SD}$ of triplicate experiments.

\section{지질과산화물 억제 효과}

Malondialdehyde(MA) 생성을 지표로 한 지질과산화물 분석은 가장 보편적이며 최종단계의 산화적 스트레스를 평가하는 방법으로 이용되고 있다(17). Fig. 4에서 4종의 식물 추출물에 대해 TBARS와 반응하는 TCA를 측정하여 지질과산화물 억제 효과를 평가하였다. 마우스의 간 조직 에서 염화제 2 철 $\left(\mathrm{FeCl}_{3}\right)$ 에 의해 야기된 지질과산화물에 대 한 억제력은 열수추출물과 효소추출물간의 차이는 크지 않았으며, 모든 실험군에서 지질과산화물을 억제하는 것으 로 나타났으며 특히 처리 시료 중 아카시아 추출물(wattle, $0.1 \mathrm{mg} / \mathrm{mL}$ )이 무처리 대조군과 비교하여 $37 \%, 34 \%$ 로 지질 과산화물 생성을 효과적으로 억제하는 것을 확인하였다.

\section{항균활성}

탄닌계 색소의 항균 효과를 알아보기 위하여 Escherichia 
coli, Listeria grayi을 이용하여 항균 활성을 측정해 본 결과 는 Table. 2과 같다. 추출물 절대량 $1 \mathrm{mg}$ 을 처리했을 때 E. coli 균에 대한 억제 효과는 열수추출물 및 효소추출물 모두에서 고르게 나타났으며, 특히 옻나무(케브라쵸) 효소 추출물의 생육 저지환이 $8 \mathrm{~mm}$ 로 가장 크게 표현 되었다. 다른 추출물에서도 $3 \mathrm{~mm}$ 내외의 뚜렷한 생육저지환이 유 지되었다. Listeria grayi에서는 열수추출물을 처리한 테스 트에서는 생육저지환이 존재하지 않았지만 효소처리 추출 물에서는 옻나무(케브라쵸)를 제외한 나머지 색소에서 3

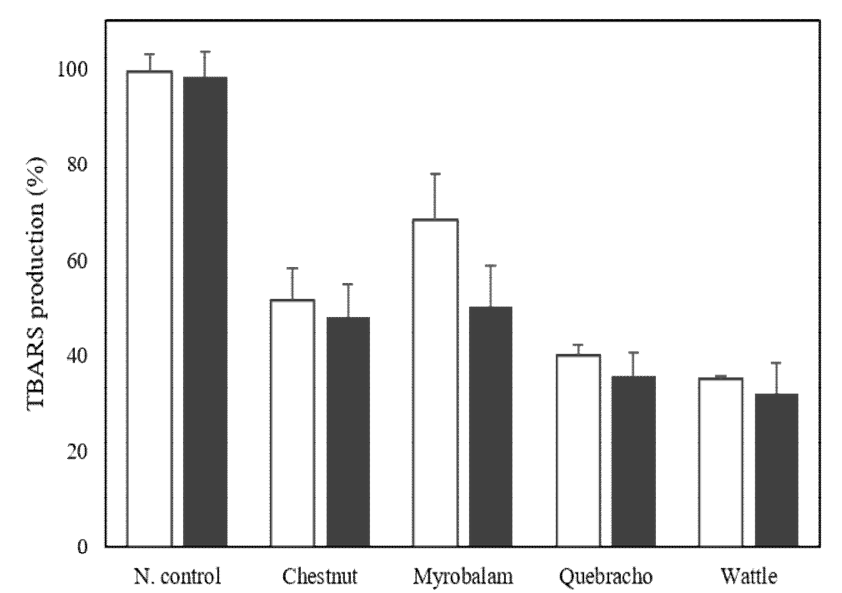

Fig. 4. Lipid peroxidation inhibition effect of hot-water extracts (open bars) and enzyme extracts (dark gray bars) from various plants.

$\mathrm{N}$. control is negative control without sample. Data are expressed as mean $\mathrm{SD}$ of triplicate experiments.

Table 2. Antibacterial activity of plant extracts on microorganisms

\begin{tabular}{ccccc}
\hline \multirow{2}{*}{ Sample } & \multicolumn{2}{c}{ Listeria grayi } & \multicolumn{2}{c}{ Escherichia coli } \\
\cline { 2 - 5 } & Hot water & Enzyme & Hot water & Enzyme \\
\hline Castanea crenata var. dulcis & - & + & + & + \\
Terminalia chebula & - & + & + & + \\
Schinopsis lorentzii & - & - & + & ++ \\
Acacia decurrens var. mollis & - & + & - & + \\
\hline
\end{tabular}

Treatment concentration of sample : $1 \mathrm{mg}$

- : No effect

+ : clear zone diameter $<5 \mathrm{~mm}$

++ : clear zone diameter $>5 \mathrm{~mm}$

Table 3. Antioxidant activities of hot-water extracts and enzyme extracts from various plants

\begin{tabular}{lccc}
\hline Sample & $\mathrm{TPC}(\mathrm{mg} / \mathrm{g})$ & $\mathrm{DPPH}\left(\mathrm{IC}_{50}\right)$ & $\mathrm{ABTS}^{+}\left(\mathrm{IC}_{50}\right)$ \\
\hline Castanea crenata var. dulcis & $0.42^{1)} / 0.77^{2)}$ & $9.4 / 5.95$ & $7.6 / 2.78$ \\
Terminalia chebula & $0.46 / 0.52$ & $21.5 / 3.7$ & $6.8 / 3.04$ \\
Schinopsis lorentzii & $0.63 / 0.78$ & $15.4 / 6.02$ & $9.2 / 2.4$ \\
Acacia decurrens var. mollis & $0.33 / 0.64$ & $12.91 / 6.58$ & $7.94 / 3.06$ \\
\hline${ }^{1)}$ Hot-water extracts & & & \\
${ }^{2)}$ Enzyme extracts & &
\end{tabular}

$\mathrm{mm}$ 내외의 뚜렷한 생육저지환을 나타내는 것으로 보아 상당한 수준의 리스테리아 저해능을 보유하는 것으로 판단 된다.

\section{요 약}

이 연구의 목적은 탄닌계 색소를 함유한 식물에 대한 열수추출물과 효소추출물의 항산화 및 항균활성을 확인하 는 것이다. 일반적으로 사용되어온 추출방법인 유기용매 사용을 피하고 효율적인 추출방법을 모색하고자 효소반응 을 적용하여 낮은 온도에서도 효과적으로 유용성분을 추출 하기 위한 방법을 제시하고자 한다. 본 실험에서 사용된 효소 중 Cellu-Bio는 추출효율을 높이는데 좋은 효과를 나 타내나 점성이 높고 엉김현상이 발생되어 이를 해소하기 위해 a-amylase를 함유하고 있는 전분분해효소(Termamyl, $\mathrm{Ban} 800 \mathrm{MG})$ 를 동시에 적용하여 추출효율 및 사용성을 높 였다.

항산화 활성은 총 페놀 함량 분석, $\mathrm{DPPH}$ 및 $\mathrm{ABTS}^{+}$라디 칼 소거능, 지질과산화물 억제반응으로 확인하였고, 항균 활성은 대장균 및 리스테리아균에 대한 억제력 테스트를 통해 항균효과를 비교 검증하였다. 열수추출물에서 $\mathrm{DPPH}$ 라디칼 소거 활성을 나타내는 $\mathrm{IC}_{50}$ 값은 9.4-21.5 $\mathrm{\mu g} / \mathrm{mL}$ 를 나타내었고, 효소추출물에서의 $\mathrm{IC}_{50}$ 값은 $3.7-6.58 \mathrm{\mu g} / \mathrm{mL}$ 를 나타내었다. 비교 물질로 주로 사용되는 ascorbic acid의 $10.5 \mathrm{\mu g} / \mathrm{mL}$ 만큼 우수한 항산화력을 가지는 것을 확인하였 다. $\mathrm{TPC}^{\text {와 }} \mathrm{ABTS}^{+}$라디칼 소거능도 모두 유의성 있게 나타 났으며, 지질과산화 반응에서도 시료를 처리하지 않은 무 처리군 대비 $50 \%$ 이상의 지질과산화물 생성을 억제하는 것으로 나타났다. 이러한 결과는 탄닌계 색소를 함유한 식 물이 우수한 항산화력을 가지며, 특히 효소추출물이 열수 추출물 보다 높은 수준의 활성을 나타내었다. 이는 낮은 온도의 효소반응을 통해 탄닌을 포함하는 폴리페놀성분이 더 많이 추출되어 높은 활성을 유지하는 것으로 판단된다. 항균활성은 리스테리아균 보다 대장균에서 항균 효과가 뛰어 났으며, 균종에 관계없이 열수추출보다 효소추출이 항균 효과가 좋게 나타내었다. 결론적으로 탄닌을 함유한 식물은 생물체의 산화적 스트레스로부터 야기되는 활성산 소를 억제하는 중요한 역할을 하며, 보다 심도 깊은 연구를 진행한다면 새로운 생물 소재로 활용성이 높을 것으로 사료 된다.

\section{감사의 글}

본 연구는 2018년도 대구대학교 학술연구비 지원에 의한 논문이며, 이에 감사드립니다. 


\section{References}

1. Lee YM, Lee JJ, Lee MY (2008) Antioxidative effect of Pimpinella brachycarps ethanol effect. J Life Sci, 18, 467-473

2. Ali KA, Abdelhak M, George B, Panagiotis K (2005) Tea and herbal infusions: Their antioxidant activity and phenolic propolis. Food Chem, 89, 27-36

3. Elzaawely AA, Xuan TD, Tawata S (2005) Antixidant and antibacterial activites of Rumex japonicus Houtt. Aerial Parts. Biol Pharm Bull, 28, 2225-2230

4. Han MR, Lee JS (2009) Fabric dyeing with myrobalan (Terminlia chebula Retz.). J Kor Soc Cloth Ind, 11, 953-960

5. Cho KR (1997) Studies on the natural dyes(9) Dying properties of acom tannin for silk fiber. J Natural Science of Pusan Women's University, 3, 207-226

6. Park SY, Nam YJ (2001) The natural coloring-matter and dying of medicinal plants. Research Institute of Science for Haman Life, 5, 51-57

7. Sato M, Ramarathnam N, Suzuki Y, Ohkubo T, Takeuchi M, Ochi H (1996) Varietal differences in the phenolic content and superoxide radical scavenging potential of wines from different sources. J Agric Food Chem, 44, 37-41

8. Szabo MR, Iditoiu C, Chambre D, Lupea AX (2007) Improved DPPH determination for antioxidant activity spectrophotometric assay, Institute of Chemistry. Chem Pap, 61, 214-216

9. Roterta R, Nicoletta P, Anna P, Ananth P, Min Y, Catherine RE (1999) Antioxidantactivity applying an improved ABTS radical cation decolorizationassay. Free radical Biology \& Medicine, 26, 1231-1237
10. Buege JA, Aust SD (1978) Microsomal lipid peroxidation. Method. Enzymol, 52, 302-310

11. Zaidan MRS, Noor Rain A, Badrul AR, Adlin A, Norazah A, Zakiah I (2005) In vitro screening of five local medicinal plants for antibacterial activity using disc diffusion method. Tropical Biomedicine, 22, 165-170

12. Duval B, Shetty K (2001) The stimulation of phenolics and antioxidant activity in pea(Pisum sativum) elicited by genetically transformed anise root extract. J Food Biochem, 25, 361-337

13. Al-sereiti MR, Abu-Amer KM, Sen P (1999) Pharmacology of rosemary (Rosmarinus officinalis Linn.) and its therapeutic potentials. J Indian Exp, 37, 124-130

14. Kim YS, Suh HJ, Park S (2013) Antioxidant and photoprotective activities of various extracts from the roots of Rumex Crispus L. Korean J Food Preserv, 20, 684-690

15. Kim YS, Suh HJ, Park S (2015) Antioxidant activity of hot-water extracts and floral waters from natural palnt pigments. Korean J Food Preserv, 22, 129-133

16. Choi YM, Kim MH, Shin JJ, Park JM, Lee JS, Kim. MH (2003) The antioxidant activites of the some commercial teas. J Korean Soc Food Sci Nur, 32, 723-727

17. Moon JK, Shibamoto T (2009) Antioxidant assays for plant and food components. J Agric Food Chem, 57, $1655-1666$ 